\title{
Upregulation of miR-375 inhibits human liver cancer cell growth by modulating cell proliferation and apoptosis via targeting ErbB2
}

\author{
LINA LI $^{1}$, LIPING JIA ${ }^{1}$ and YAN DING ${ }^{2}$ \\ ${ }^{1}$ Department of Digestive Diseases, Daqing Longnan Hospital, Daqing, Heilongjiang 163453; \\ ${ }^{2}$ The First Department of General Surgery, Daqing Oilfield General Hospital, Daqing, Heilongjiang 163000, P.R. China
}

Received September 1, 2016; Accepted December 6, 2017

DOI: $10.3892 / \mathrm{ol} .2018 .9011$

\begin{abstract}
RNAs (miRNA/miRs) are a class of small non-coding RNAs; they serve important biological roles in tumorigenesis through the regulation of oncogene expression, and they may be used for the diagnosis and treatment of human cancer. miR-375 was identified to exhibit abnormal expression levels in a number of types of tumor; however, the biological role of miR-375 in human hepatocellular carcinoma (HCC) remains incompletely characterized. The present study investigated the expression of miR-375 in human HCC tissues and human liver cancer cell lines; results from a reverse transcription quantitative polymerase chain reaction analysis indicated that the expression of miR-375 was significantly decreased in tissues and live cancer cell lines, compared with normal tissues and PHH cells. Additional studies demonstrated that the upregulation of miR-375 inhibited human liver cancer cell growth via regulation of cell apoptosis. It was also revealed that the receptor tyrosine-protein kinase erbB-2 (ErbB2) gene was a direct target gene of miR-375, and that the regulation of ErbB2 was associated with the human liver cancer growth. Therefore, the present study demonstrated that miR-375 was expressed at low levels both in human HCC tissues and cell line, compared with normal tissues and $\mathrm{PHH}$ cells, and that the induction of miR-375 expression may regulate human liver cancer cell function through targeting the ErbB2 gene, which may potentially improve the diagnosis and treatment of patients with HCC in the future.
\end{abstract}

\section{Introduction}

microRNAs (miRs) are a class of non-coding small RNAs that serve important roles in carcinogenesis. They regulate gene expression by binding to the 3 'untranslated regions (3'UTR) of

Correspondence to: Dr Yan Ding, The First Department of General Surgery, Daqing Oilfield General Hospital, 9 Zhongkang Street, Daqing, Heilongjiang 163000, P.R. China

E-mail: yanding_dq@yeah.net

Key words: microRNA-375, human liver cancer cell, proliferation, apoptosis, receptor tyrosine-protein kinase erbB-2 target genes $(1,2)$, which leads to gene transcription, regulation or mRNA degradation $(3,4)$. A number of the regulated genes are oncogenes or tumor suppressors (5-7). miRs regulation may inhibit cancer cell proliferation and induce cell apoptosis $(8,9)$. A previous study indicated that miR modulation therapy may affect multiple target genes, which may potentially improve clinical treatments (10). In previous decades, studies have identified that in human hepatocellular carcinoma (HCC), there are a number of important aberrantly expressed miRs, and that these abnormal miRs were associated with HCC development (11-16). However, the majority of the biological roles of miRs in HCC remain incompletely understood.

$\mathrm{HCC}$ is a type of cancer that originates in the hepatocytes, and there are $>500,000$ people diagnosed with liver cancer each year globally (17). It occurs most commonly in countries where viral Hepatitis B and C infections are common $(16,18)$ and with no perfected targeted therapies, the $<5$-year survival rate of $\mathrm{HCC}$ is $5 \%$ (19). Previous studies have indicated that miRs regulate essential signal pathways in liver cancer: miR-21 is highly overexpressed in liver cancer and the downregulation of miR-21 inhibits HCC cell proliferation, migration and invasion by targeting the PTEN tumor suppressor $(5,20,21)$. Previous studies have also indicated that the expression of miR-34a is downregulated in human HCC $(22,23)$, and that miR-34a regulates the biological function of HCC cells by targeting the tumor suppressor p53 (24). These studies demonstrated that miRs may serve important roles in human HCC tumorigenesis by regulating the expression of genes. miR-375 was identified to be abnormally expressed in numerous types of cancer (25-27); however, the biological role of miR-375 in human HCC remains incompletely understood. The present study aimed to investigate whether the miR-375 is involved in the human HCC tumorigenesis, and to identify the mechanism of action.

\section{Materials and methods}

HCC cell lines and patient samples. Human liver cancer cell lines (Huh7, SK-HEP-1, MHCC97-H, MHCC97-L and Hep3B2.1-7) were purchased from the Cell Bank of Type Culture Collection of the Chinese Academy of Sciences (Shanghai, China). Primary human hepatocyte (PHH) cells (cat. no. M00995) were purchased from the Research Institute for Liver Diseases Shanghai, Co., Ltd. (Shanghai, China). 
Liver cancer cell lines were cultured in Dulbecco's modified Eagle medium (DMEM; Gibco; Thermo Fisher Scientific, Inc., Waltham, MA, USA) supplemented with $10 \%$ fetal bovine serum (FBS; Gibco; Thermo Fisher Scientific, Inc.), $100 \mathrm{IU} / \mathrm{ml}$ penicillin (Gibco; Thermo Fisher Scientific,Inc.) and $100 \mathrm{mg} / \mathrm{ml}$ streptomycin (Gibco; Thermo Fisher Scientific, Inc.). The PHH incubation media (cat. no. PY-HMD-01) was also purchased from the Research Institute for Liver Diseases Shanghai, Co., Ltd. Patients with HCC were collected from Daqing Longnan Hospital (Daqing, China) and 43 pairs (23 male; 20 female; age range, 31-63; median age, 47) of HCC and noncancerous normal tissue samples ( $>30 \mathrm{~mm}$ away from the tumor) were obtained from these patients via surgical resection. Samples were stored in RNAlater ${ }^{\mathrm{TM}}$ (Ambion; Thermo Fisher Scientific, Inc.) at $-80^{\circ} \mathrm{C}$ until use. The collection of patient tissues was performed following the Ethical and Institutional Guidelines (Daqing LongNan Hospital, Daqing, China) and subsequent to provision of written informed consent from all patients. The present study was approved by the Medical Ethics Committee of Daqing Longnan Hospital.

Transfection assay. Huh7 cells were cultured in RPMI-1640 medium (Gibco; Thermo Fisher Scientific, Inc.) supplemented with $10 \% \mathrm{FBS}$ at $37^{\circ} \mathrm{C}$ overnight, then the miR-375 mimics were transfected into the cells (10 $\mathrm{nM}$ final concentration) using Lipofectamine ${ }^{\circledR} 2000$ (Invitrogen; Thermo Fisher Scientific, Inc.) as previously described (28); the control mimic was used as the control. The miR-375 and control mimics were purchased from Thermo Fisher Scientific, Inc. Small interfering (si)RNA (cat. no. sc-400138-KO-2) was purchased from Santa Cruz Biotechnology, Inc., (Dallas, TX, USA). The protocol used for receptor tyrosine-protein kinase erbB-2 (ErbB2) knockdown was performed as previously described (50 nM final concentration) (29).

miR-375 quantification using reverse transcription quantitative polymerase chain reaction (RT- $q P C R)$. Total RNA for miR-375 quantification was extracted from human HCC tissue samples and cells using TRIzol ${ }^{\circledast}$ reagent (Thermo Fisher Scientific, Inc.) and reverse transcribed $\left(42^{\circ} \mathrm{C}, 60 \mathrm{~min}\right.$; $85^{\circ} \mathrm{C}, 5 \mathrm{~min}$ ) into cDNA with the TaqMan miRNA Reverse Transcription kit (Applied Biosystems; Thermo Fisher Scientific, Inc.) with a miRNA-specific looped RT primer (Applied Biosystems; Thermo Fisher Scientific, Inc.). Then, the expression of miR-375 was evaluated using TaqMan Universal PCR Master Mix with miRNA-specific TaqMan minor groove binder probes (Thermo Fisher Scientific, Inc.). The qPCR primers used were commercially available (cat. no. Hs04231554_s1; Applied Biosystems; Thermo Fisher Scientific, Inc.). qPCR was performed using the followed program: $95^{\circ} \mathrm{C}$ for $10 \mathrm{~min} ; 95^{\circ} \mathrm{C}$ for $10 \mathrm{sec}, 57^{\circ} \mathrm{C}$ for $20 \mathrm{sec}$ and $72^{\circ} \mathrm{C}$ for $10 \mathrm{sec}$ for 40 cycles, using the LightCycler 480 Real-Time PCR System (Roche Diagnostic, Basel, Switzerland). RNA U6 (cat. no. Hs00984809_m1; Applied Biosystems; Thermo Fisher Scientific, Inc.) was used as an internal control. Expression of miR-375 relative to U6 was determined using the $2^{-\Delta \Delta \mathrm{Cq}}$ method (30).

Cell viability assay. Human HCC Huh7 cells were cultured in 96-well plate (3,000 cell/well); the Cell Counting Kit-8 (CCK8) assay was performed to test the cell viability every $24 \mathrm{~h}(0,24$, 48, 72 and 96 h). Firstly, CCK8 reagent (Beyotime Institute of Biotechnology, Haimen, China) was added in to the well at 1:10 dilution, and then incubated with the cells for an additional $2 \mathrm{~h}$ at $37^{\circ} \mathrm{C}$. Finally, the absorbance (OD450) of the 96-well plate was measured. The absorbance was expressed as the cell viability.

Colony formation assay. A total of $24 \mathrm{~h}$ following transfection, Huh7 cells were seeded into 6-well plates at $\sim 550$ cells/well. The culture medium was changed every other day, and the 6-well plates were cultured for 2 weeks. Colonies were fixed with $100 \%$ methanol at room temperature for $15 \mathrm{~min}$ and stained using crystal violet $(0.5 \%)$ at $4^{\circ} \mathrm{C}$ for $30 \mathrm{~min}$. The colony formation ability was evaluated by counting the number of colonies formed with a light microscope (magnification $\mathrm{x} 4$ ).

Cell apoptosis assay. A total of $24 \mathrm{~h}$ following transfection, Huh7 cells were seeded onto 6-well plates $(1,200,000 /$ well $)$ and cultured at $37^{\circ} \mathrm{C}$ for an additional $48 \mathrm{~h}$. Then, the cells were harvested and stained with Annexin V $(1 \mu \mathrm{g} / \mathrm{ml})$ and propidium iodide $(2 \mu \mathrm{g} / \mathrm{ml})$ at $4^{\circ} \mathrm{C}$ for $15 \mathrm{~min}$ (Beyotime Institute of Biotechnology). Cell apoptosis was evaluated using flow cytometry and CellQuest Pro software (version 5.1; BD FACSCalibur; BD Biosciences, CA, USA).

MiRNA target predictions. To additionally investigate the potential target of miR-375, potential genes identified by computer-aided algorithms were obtained from targetscan (http://www.targetscan.org) and mirbase targets (http://microrna. sanger.ac.uk/cgi-bin/targets/v5/search.pl).

Dual-luciferase assay. The wild-type (WT) or mutant (Mut) ErbB2 3'-UTRs reporter vector (Qcbio S\&T Co., Ltd, Shanghai, China) were co-transfected with the miR-375 mimic or control mimic (10 $\mathrm{nM}$ final concentration) into Huh7 cells using Lipofectamine ${ }^{\circledast} 2000$ in 96 -well plates $(10,000$ cells/well). The duration between transfection and activity measurement was $24 \mathrm{~h}$. The transfected cells were cultured at $37^{\circ} \mathrm{C}$ for an additional $24 \mathrm{~h}$ and harvested; Cells were then lysed as the followed protocol: Removal of the growth medium; washing the cells with PBS 3 times; adding $20 \mu \mathrm{l}$ PLB buffer (Promega Corporation, Madison, WI, USA) into each well; shaking the solutions via gentle rocking for $15 \mathrm{~min}$; performing reporter assays directly in the wells of the culture plate (Promega Corporation). The firefly luciferase activity was examined by the dual-luciferase reporter assay (Promega Corporation). Relative luciferase activity was normalized with the Renilla luciferase activity. The kit used to measure activity was the Dual-Luciferase ${ }^{\circledR}$ Reporter Assay System (Promega Corporation).

RT-qPCR for ErbB2. Total RNA was extracted from Huh7 cells using TRIzol ${ }^{\circledR}$ reagent (Life Technologies; Thermo Fisher Scientific, Inc.) and reverse transcribed into cDNA with the Reverse Transcriptase MMLV (Takara Biomedical Technology Co., Ltd. Dalian, China). Program for reverse transcription: $10 \mathrm{~min}$ at $30^{\circ} \mathrm{C}, 60 \mathrm{~min}$ at $42^{\circ} \mathrm{C}$ and $5 \mathrm{~min}$ at $95^{\circ} \mathrm{C}$. qPCR $\left(\mathrm{SYBR}^{\circledR}\right.$ Green; FastStart Universal SYBR Green Master; Roche Diagnostics) was performed using the LightCycler480 Real-Time PCR System (Roche Diagnostics) and the following thermocycling parameters: $95^{\circ} \mathrm{C}$ for $10 \mathrm{~min}$, followed by 


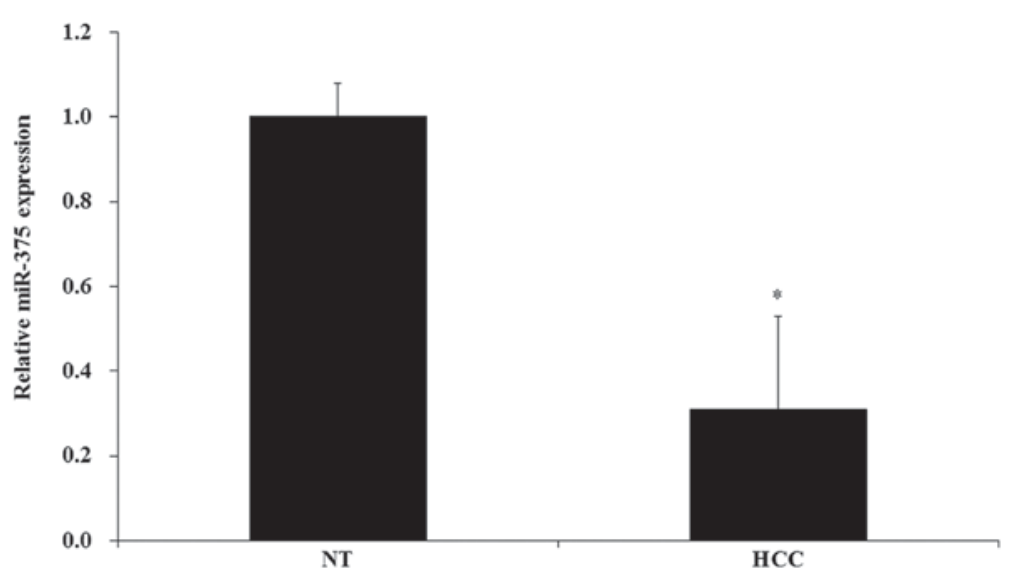

Figure 1. Expression level of miR-375 in human HCC tissues. The miR-375 level was measured by reverse transcription quantitative polymerase chain reaction. The data are expressed as the mean \pm standard deviation. " $\mathrm{P}<0.05$. miR, microRNA; HCC, hepatocellular carcinoma; NT, non-tumor.

40 cycles of $15 \mathrm{sec}$ at $95^{\circ} \mathrm{C}, 30 \mathrm{sec}$ at $60^{\circ} \mathrm{C}$ and $20 \mathrm{sec}$ at $72^{\circ} \mathrm{C}$. The primers used were as follows: ErbB2: Forward, $5^{\prime}-\mathrm{CCA}$ GCCTTCGACAACCTCTATT-3', and reverse, 5'-TGCCGT AGGTGTCCCTTTG-3'. $\beta$-actin: Forward, 5'-ATCTGGCAC CACACCTTCTACAAT-3', and reverse 5'-CCGTCACCG GAGTCCATCA-3'. Expression of ErbB2 relative to $\beta$-actin was determined using the $2^{-\Delta \Delta \mathrm{Cq}}$ method (30).

Western blotting assay. A total of $24 \mathrm{~h}$ following transfection, Huh7 were seeded into 6 -well plates and cultured at $37^{\circ} \mathrm{C}$ for an additional $48 \mathrm{~h}$. Cells were harvested and protein was extracted by using the commercial kit (Cell Lysis Buffer; Applygen Technologies Inc., Beijing, China). Subsequently, the proteins $(50 \mu \mathrm{g})$ were separated using a 10\% gel and SDS-PAGE and the separated proteins were transferred to a polyvinylidene fluoride (PVDF) membrane. The transferred PVDF membrane was blocked with blocking buffer ( $5 \%$ dried milk) at room temperature for $1 \mathrm{~h}$, and then the membrane was incubated with primary antibodies against ErbB2 (dilution, 1:1,000; cat. no. 2242; Cell Signaling Technology, Inc., Danvers, MA, USA) and $\beta$-actin (dilution, 1:5,000; cat. no. 4967; Cell Signaling Technology, Inc.) at room temperature for $2 \mathrm{~h}$. The PVDF membrane was washed with TBST 3 times and incubated with the secondary antibody (goat anti-rabbit; dilution, 1:1,000; cat. no. A0208; Beyotime Institute of Biotechnology) at room temperature for $1 \mathrm{~h}$. The membrane was then washed again with TBST 3 times, and the proteins were examined using an electrochemiluminescence kit (cat. no. P0018; Beyotime Institute of Biotechnology) and exposed to x-ray film.

Statistical analysis. A one-way analysis of variance and Student-Newman-Keuls test (post hoc test) were performed to analyze the statistical difference by using SPSS v13.0 software (SPSS, Inc., Chicago, IL, USA). Data were expressed as mean \pm standard deviation. Each experiment was performed in triplicate. $\mathrm{P}<0.05$ was considered to indicate a statistically significant difference.

\section{Results}

miR-375 is downregulated in human HCC. Previous studies have demonstrated that ErbB2 gene upregulation is an important contributing factor to hepatocellular growth (31), and that ErbB2 upregulation was associated with miR-375 regulation (32). The present study aimed to examine the miR-375 level in human liver cancer tissues and cell lines. A total of 43 pairs of HCC and matched adjacent non-tumor tissues were analyzed, and the RT-qPCR results indicated that the level of miR-375 was significantly decreased in HCC tissues compared with the non-tumor tissues $(\mathrm{P}<0.05$; Fig. 1).

Subsequently, the miR-375 level was examined in liver cancer cell lines; 5 liver cell lines were used, and PHH was used as the normal control. The RT-qPCR results indicated that the miR-375 level was also significantly decreased in the 5 liver cancer cell lines compared with the normal $\mathrm{PHH}$ cell line ( $\mathrm{P}<0.05$; Fig. 2). Therefore, miR-375 was downregulated in HCC tissues and HCC cell lines.

Manipulation of miR-375 levels in HCC cells. To additionally investigate the biological activity of miR-375 in HCC cells, the expression of miR-375 was manipulated by transfection of miR-375 mimics. Huh7 cells were cultured, then transfected with miR-375 or control mimics and cultured for an additional $48 \mathrm{~h}$. Then, cells were harvested and an RT-qPCR assay was performed to examine the expression of miR-375. The RT-qPCR results demonstrated that transfection of the miR-375 mimic significantly increased the expression of miR-375 compared with the control mimic-transfected and mock cells $(\mathrm{P}<0.05$; Fig. 3$)$.

Upregulation of miR-375 inhibits HCC cell proliferation. To study the biological activity of miR-375 in HCC cell proliferation, mock and transfected Huh7 cells were cultured, and the cell proliferation was evaluated by CCK8 assay. The results indicated that the induction of miR-375 expression significantly decreased the HCC cell proliferation compared with the mock and control mimic-transfected cells $(\mathrm{P}<0.05$; Fig. 4). Furthermore, the colony-formation assay results indicated that the induction of miR-375 expression significantly decreased the colony numbers compared with the numbers in the mock cell group $(\mathrm{P}<0.05)$, while transfection with the control mimic did not affect the colony numbers (Fig. 5). 


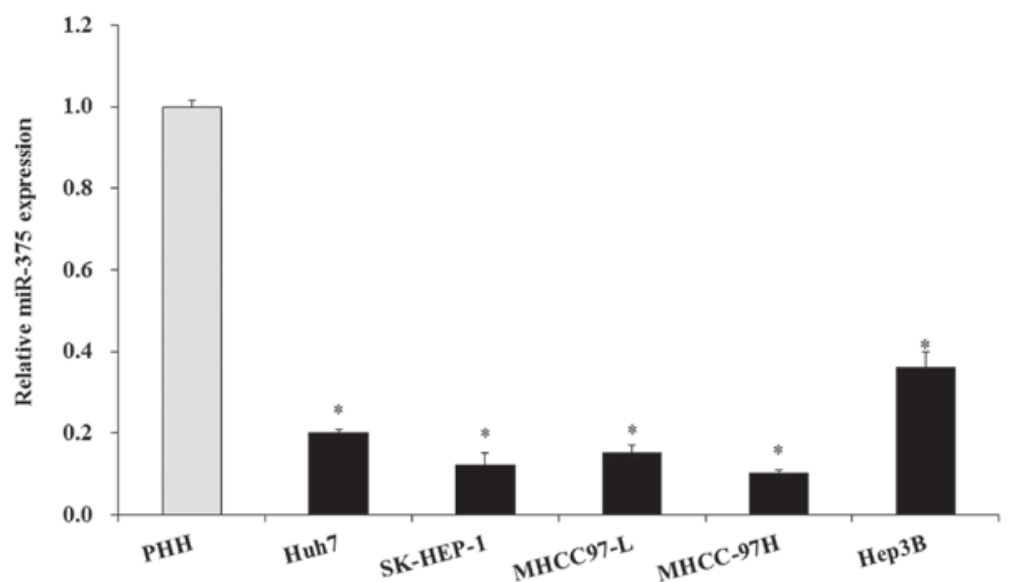

Figure 2. Expression level of miR-375 in human HCC cells. The miR-375 level was measured by reverse transcription quantitative polymerase chain reaction. The data are expressed as the mean \pm standard deviation. " $\mathrm{P}<0.05$ (compared with the PHH group). miR, microRNA; HCC, hepatocellular carcinoma.

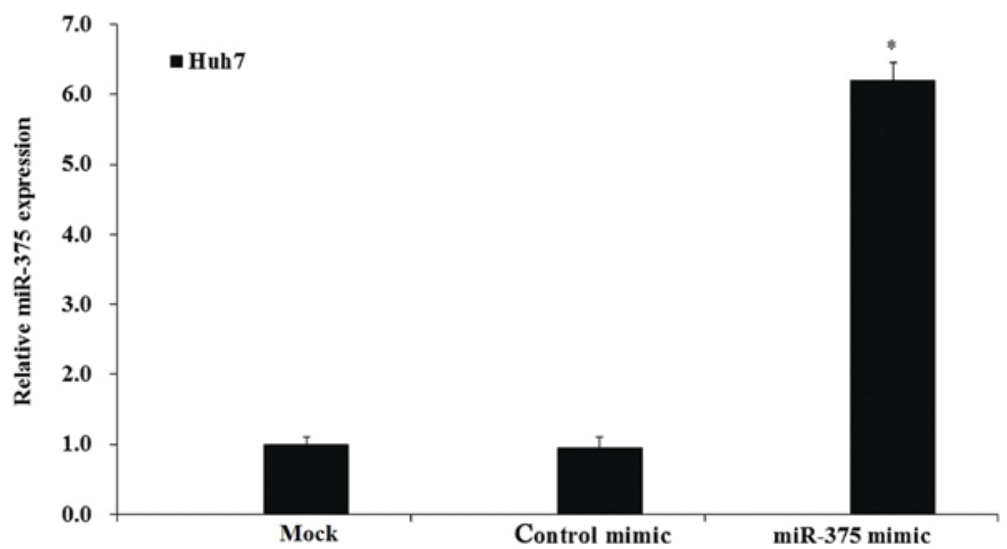

Figure 3. Expression level of miR-375 in mimic-transfected human hepatocellular carcinoma cells. The miR-375 level was measured by reverse transcription quantitative polymerase chain reaction. The data are expressed as the mean \pm standard deviation. ${ }^{*} \mathrm{P}<0.05$ (compared with the control and mock groups). miR, microRNA.

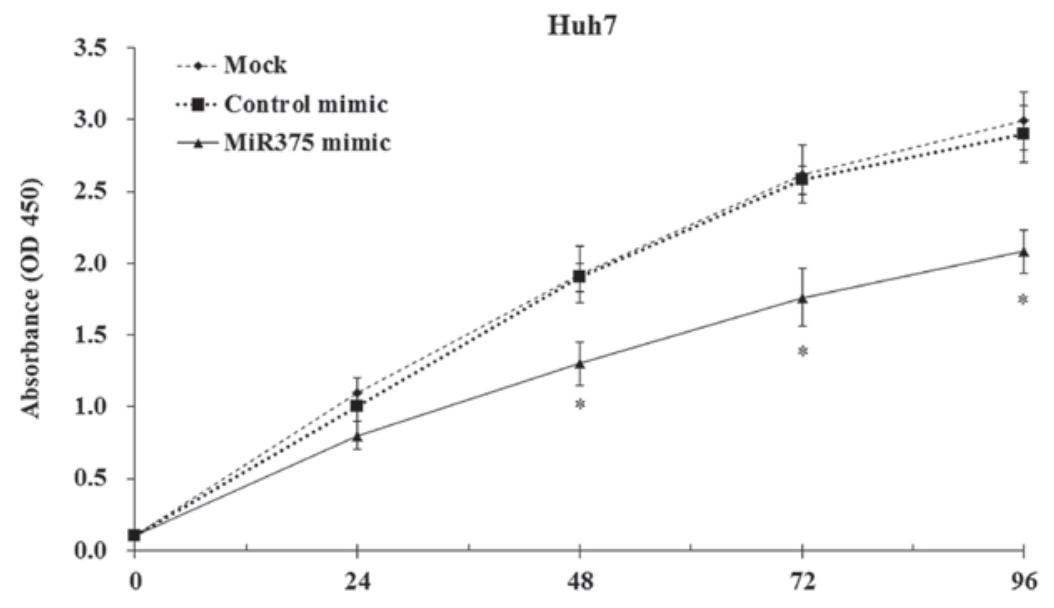

Figure 4. Effect of miR-375 on human hepatocellular carcinoma cells survival curves. Cell viability was measured by Cell Counting Kit-8 assay. The data are expressed as the mean \pm standard deviation. ${ }^{*} \mathrm{P}<0.05$ (compared with the control and mock groups). miR, microRNA; OD, optical density.

Upregulation of miR-375 induces HCC cell apoptosis. To confirm whether the proliferation inhibition was associated with cell apoptosis, the effect of miR-375 induction on the cell apoptosis was investigated. Mock and transfected Huh7 cells were cultured and the cell apoptosis was evaluated by flow cytometry. The results indicated that miR-375 mimic transfection significantly induced the HCC cell apoptosis to $7 \%$, compared with $0.8 \%$ in the mock and $0.9 \%$ in control groups $(\mathrm{P}<0.05$; Fig. 6). 


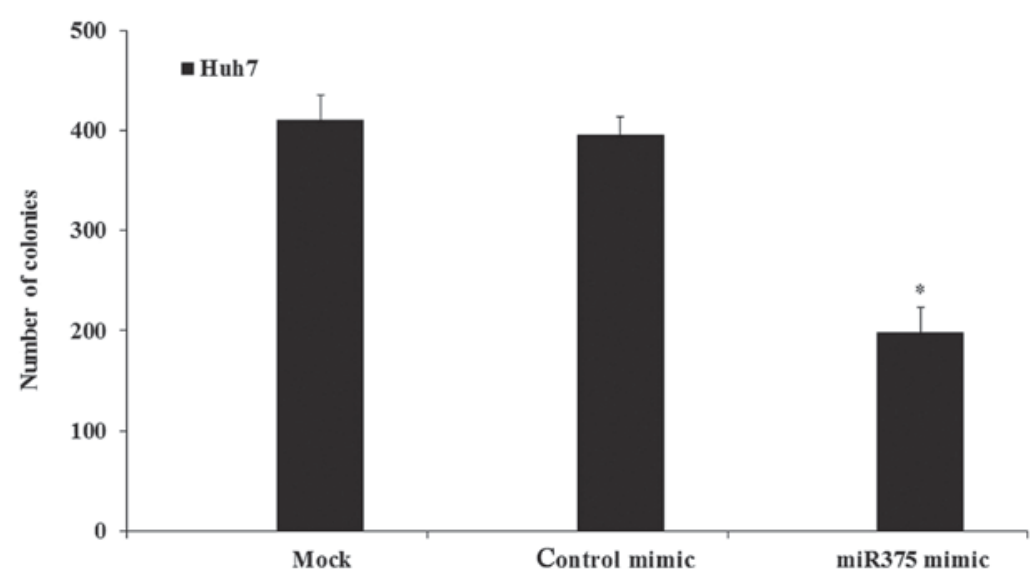

Figure 5. Effect of miR-375 on colony formation. The data are expressed as the mean \pm standard deviation. ${ }^{*}<<0.05$ (compared with the control and mock groups). miR, microRNA.

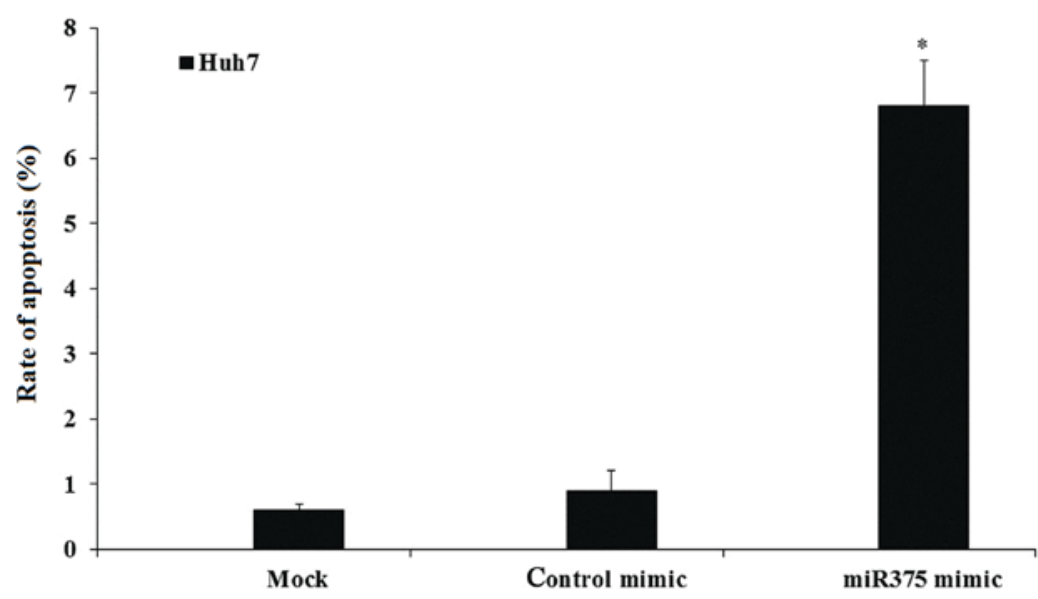

Figure 6. Effect of miR-375 on human hepatocellular carcinoma cell apoptosis. The cell apoptosis was evaluated by flow cytometry. The data are expressed as the mean \pm standard deviation. ${ }^{*} \mathrm{P}<0.05$ (compared with the control and mock groups).

ErbB2 is a direct target of miR-375. It was identified that ErbB2 is a potential gene of miR-375 (Fig. 7A). To confirm whether ErbB2 is a direct target of miR375, a dual luciferase assay was performed. The miR-375 mimic and pGL2-ErbB2 (WT and Mut) were co-transfected into Huh7 cells; control mimics were used as the control. The results indicated that transfection of miR-375 mimic significantly decreased the luciferase in Huh7 cells compared with control mimic-transfected Huh7 cells, while the decrease was not observed in the Mut pGL2-ErbB2 group (Fig. 7B). Therefore, these results demonstrated that ErbB2 is a direct target gene of miR-375.

miR-375 modulates HCC cell growth by repressing ErbB2. To study whether miR-375 regulated HCC cell growth through targeting the ErbB2 gene, the expression of ErbB2 in HCC cells was examined by RT-qPCR assay. The results indicated that ErbB2 expression in Huh7 cells was increased compared with normal PHH (data not shown). Then, miR-375 mimics were transfected into Huh7 cells, and it was identified that the expression of ErbB2 was significantly inhibited at the protein and mRNA levels compared with the control mimic and mock groups (Fig. 8A and B). To analyze whether the decrease in ErbB2 expression was associated with HCC cell growth, HCC cells were transfected with ErbB2 siRNA and the cell viability was measured by CCK- 8 assay. The results indicated that transfection of ErbB2 siRNA significantly inhibited the cell viability compared with the control and mock groups (Fig. 8C). Therefore, it was concluded that the expression of ErbB2 was associated with HCC cell growth, and that miR-375 modulated the cell growth by repressing the expression of ErbB2.

\section{Discussion}

miRs are a class of non-coding small RNAs measuring $\sim 22$ nucleotides in length. They serve important roles in the translation or degradation of mRNAs (32). Previous studies have demonstrated that miRs may regulate oncogene expression in tumorigenesis (33-35). miR-375 was primary identified in the human pancreas in 2004 (36), and Avnit-Sagi et al (37) suggested that miR-375 was expressed at a very high level in human pancreatic islets and brain tissue. Previous studies also identified that miR-375 was involved in numerous types of cancer (38-40): The expression of miR-375 was downregulated in human gastric cancer cells, and the induction of miR-375 expression may affect the biological function of cells (41); 

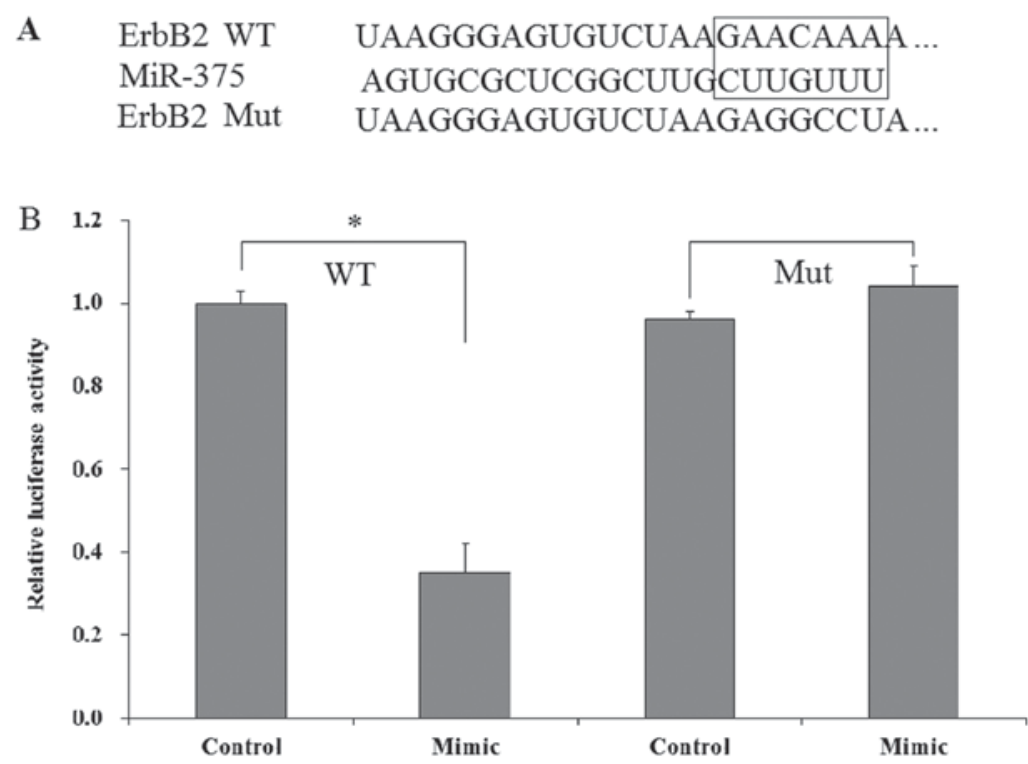

Figure 7. ErbB2 was a direct target of miR-375. (A) Prediction of miR-375 binding sites in the 3' untranslated regions of human ErbB2 gene. (B) ErbB2 as a direct target of miR-34a was confirmed by a dual-luciferase assay. The data are expressed as the mean \pm standard deviation. "P<0.05. ErbB2, receptor tyrosine-protein kinase erbB-2; WT, wild type; Mut, mutant; miR, microRNA.

$\mathbf{A}$
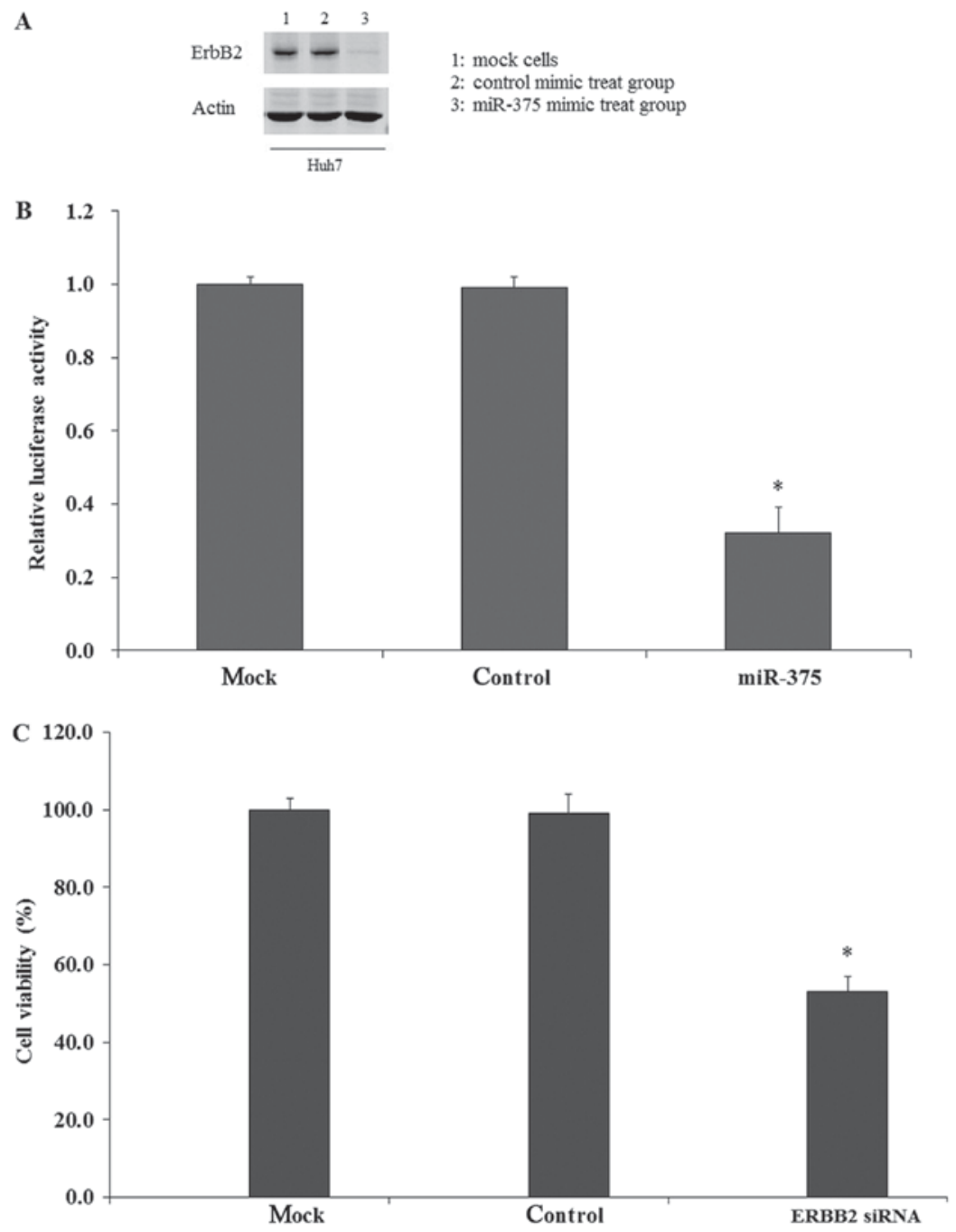

Figure 8. miR-375 modulated HCC cell growth by repressing ErbB2. (A) The expression of ErbB2 protein in human HCC cells. (B) The expression of ErbB2 mRNA in human HCC cells. (C) Cell viability of human HCC cells. Cell viability was measured by Cell counting kit 8 assay. The data are expressed as the mean \pm standard deviation. " $\mathrm{P}<0.05$ (compared with the control and mock groups). ErbB2, receptor tyrosine-protein kinase erbB-2; HCC, hepatocellular carcinoma; siRNA, small interfering RNA. 
Zhang et al (42) also identified that miR-375 expression was abnormally regulated in pancreatic progenitor cells, and that the regulation of miR-375 expression may inhibit cell proliferation through targeting Yes associated protein 1. However, the biological effect of miR-375 in human liver cancer has not been fully studied.

In the present study, the expression level of miR-375 in human HCC tissues and cell lines was evaluated; it was demonstrated that miR-375 was significantly downregulated in human HCC tissues and cell lines compared with normal liver tissues and cells, therefore we hypothesized that miR-375 served important biological roles in human liver cancer. Additional analysis indicated that the induction of miR-375 may inhibit human HCC cell proliferation and induce apoptosis. Therefore, the regulation of miR-375 served important roles in human HCC tumorigenesis in vitro. The in vivo effect is also important: The present study did not analyze the in vivo effect of miR-375 in HCC cells; this will be performed as part of future studies. Furthermore, the present study identified and confirmed that ErbB2 is a direct target of miR-375. ErbB2 belongs to the epidermal growth factor receptor family; it has been identified to serve important roles in the development and progression of different types of human cancer $(41,43)$. Previous studies have indicated that ErbB2 gene upregulation is an important contributor to hepatocellular growth, and that ErbB2 upregulation was associated with miR-375 regulation $(29,31)$. In the present study, it was identified that downregulation of ErbB2 inhibited HCC cell growth using a siRNA transfection assay. It was also demonstrated that the induction of miR-375 significantly decreased the expression of ErbB2 at mRNA and protein levels. However, the association between HCC cell apoptosis and decreased ErbB2 remains unknown, and additional studies are required.

Taken together, the present study demonstrated that miR-375 was downregulated in human HCC, and the induction of miR-375 may inhibit cell growth and induce cell apoptosis. The present study also indicated that miR-375 regulated the biological functions of HCC cells by targeting the ErbB2 gene, suggesting that miR-375 may be a potential diagnostic and therapeutic target for human $\mathrm{HCC}$ in the future.

\section{Acknowledgements}

Not applicable.

\section{Funding}

No funding was received.

\section{Availability of data and materials}

The datasets used and analyzed during the current study are available from the corresponding author on reasonable request.

\section{Authors' contributions}

LL, LJ and YD designed the study; LL and LJ performed the experiments; LL, LJ and YD analyzed the data and prepared the manuscript. YD reviewed the manuscript. All authors read and approved the final manuscript.

\section{Ethics approval and consent to participate}

The Medical Ethics Committee of Daqing Longnan Hospital approved the present study with written informed consent from all patients.

\section{Patient consent for publication}

The present study was performed following the Ethical and Institutional Guidelines with written informed consent from all patients, and in the current manuscript no information of these patients was disclosed.

\section{Competing interests}

The authors declare that they have no competing interests.

\section{References}

1. Chi SW, Zang JB, Mele A and Darnell RB: Argonaute HITS-CLIP decodes microRNA-mRNA interaction maps. Nature 460: 479-486, 2009.

2. Hale BJ, Yang CX and Ross JW: Small RNA regulation of reproductive function. Mol Reprod Dev 81: 148-159, 2014.

3. Farazi TA, Spitzer JI, Morozov P and Tuschl T: MiRNAs in human cancer. J Pathol 223: 102-115, 2011.

4. Bartel DP: MicroRNAs: Genomics, biogenesis, mechanism, and function. Cell 116: 281-297, 2004.

5. Meng F, Henson R, Wehbe-Janek H, Ghoshal K, Jacob ST and Patel T: MicroRNA-21 regulates expression of the PTEN tumor suppressor gene in human hepatocellular cancer. Gastroenterology 133: 647-658, 2007.

6. Johnson SM, Grosshans H, Shingara J, Byrom M, Jarvis R, Cheng A, Labourier E, Reinert KL, Brown D and Slack FJ: RAS is regulated by the let-7 microRNA family. Cell 120: 635-647, 2005.

7. Lee YS and Dutta A: The tumor suppressor microRNA let-7 represses the HMGA2 oncogene. Genes Dev 21: 1025-1030, 2007.

8. Calin GA and Croce CM: MicroRNA signatures in human cancers. Nat Rev Cancer 6: 857-866, 2006.

9. Ding J, Huang S, Wu S, Zhao Y, Liang L, Yan M, Ge C, Yao J, Chen T, Wan D, et al: Gain of miR-151 on chromosome 8q24.3 facilitates tumour cell migration and spreading through downregulating RhoGDIA. Nat Cell Biol 12: 390-399, 2010.

10. Kota J, Chivukula RR, O'Donnell KA, Wentzel EA, Montgomery CL, Hwang HW, Chang TC, Vivekanandan P, Torbenson M, Clark KR, et al: Therapeutic microRNA delivery suppresses tumorigenesis in a murine liver cancer model. Cell 137: 1005-1017, 2009.

11. Jiang J, Gusev Y, Aderca I, Mettler TA, Nagorney DM, Brackett DJ, Roberts LR and Schmittgen TD: Association of MicroRNA expression in hepatocellular carcinomas with hepatitis infection, cirrhosis, and patient survival. Clin Cancer Res 14: 419-427, 2008

12. Gramantieri L, Ferracin M, Fornari F, Veronese A, Sabbioni S, Liu CG, Calin GA, Giovannini C, Ferrazzi E, Grazi GL, et al: Cyclin G1 is a target of miR-122a, a microRNA frequently down-regulated in human hepatocellular carcinoma. Cancer Res 67: 6092-6099, 2007.

13. Huang YS, Dai Y, Yu XF, Bao SY, Yin YB, Tang M and Hu CX: Microarray analysis of microRNA expression in hepatocellular carcinoma and non-tumorous tissues without viral hepatitis. J Gastroenterol Hepatol 23: 87-94, 2008.

14. Budhu A, Jia HL, Forgues M, Liu CG, Goldstein D, Lam A, Zanetti KA, Ye QH, Qin LX, Croce CM, et al: Identification of metastasis-related microRNAs in hepatocellular carcinoma. Hepatology 47: 897-907, 2008.

15. Varnholt H, Drebber U, Schulze F, Wedemeyer I, Schirmacher P, Dienes HP and Odenthal M: MicroRNA gene expression profile of hepatitis C virus-associated hepatocellular carcinoma. Hepatology 47: 1223-1232, 2008.

16. Kumar V, Fausto N and Abbas A (eds): Robbins \& Cotran Pathologic Basis of Disease. 9th edition. Saunders, Philadelphia, PA, pp870-873, 2015. 
17. El-Serag HB: Hepatocellular carcinoma. N Engl J Med 365: $1118-1127,2011$.

18. Forner A, Llovet JM and Bruix J: Hepatocellular carcinoma. Lancet 379: 1245-1255, 2012

19. Hao K, Luk JM, Lee NP, Mao M, Zhang C, Ferguson MD, Lamb J, Dai H, Ng IO, Sham PC and Poon RT: Predicting prognosis in hepatocellular carcinoma after curative surgery with common clinicopathologic parameters. BMC Cancer 9: 389, 2009.

20. Volinia S, Calin GA, Liu CG, Ambs S, Cimmino A, Petrocca F, Visone R, Iorio M, Roldo C, Ferracin M, et al: A microRNA expression signature of human solid tumors defines cancer gene targets. Proc Natl Acad Sci USA 103: 2257-2261, 2006.

21. Connolly E, Melegari M, Landgraf P, Tchaikovskaya T, Tennant BC, Slagle BL, Rogler LE, Zavolan M, Tuschl T and Rogler CE: Elevated expression of the miR-17-92 polycistron and miR-21 in hepadnavirus-associated hepatocellular carcinoma contributes to the malignant phenotype. Am J Pathol 173: 856-864, 2008

22. Yang F, Li QJ, Gong ZB, Zhou L, You N, Wang S, Li XL, Li JJ, An JZ, Wang DS, et al: MicroRNA-34a targets Bcl-2 and sensitizes human hepatocellular carcinoma cells to sorafenib treatment. Technol Cancer Res Treat 13: 77-86, 2014.

23. Dang Y, Luo D, Rong M and Chen G: Underexpression of miR-34a in hepatocellular carcinoma and its contribution towards enhancement of proliferating inhibitory effects of agents targeting c-MET. PLoS One 8: e61054, 2013.

24. Xiao Z, Li CH, Chan SL, Xu F, Feng L, Wang Y, Jiang JD, Sung JJ, Cheng $\mathrm{CH}$ and Chen Y: A small-molecule modulator of the tumor-suppressor miR34a inhibits the growth of hepatocellular carcinoma. Cancer Res 74: 6236-6247, 2014.

25. Tsukamoto Y, Nakada C, Noguchi T, Tanigawa M, Nguyen LT, Uchida T, Hijiya N, Matsuura K, Fujioka T, Seto M and Moriyama M: MicroRNA-375 is downregulated in gastric carcinomas and regulates cell survival by targeting PDK1 and 14-3-3zeta. Cancer Res 70: 2339-2349, 2010.

26. Shen Y, Wang P, Li Y, Ye F, Wang F, Wan X, Cheng X, Lu W and $\mathrm{Xie} \mathrm{X}$ : MiR-375 is upregulated in acquired paclitaxel resistance in cervical cancer. Br J Cancer 109: 92-99, 2013

27. Yan JW, Lin JS and He XX: The emerging role of miR-375 in cancer. Int J Cancer 135: 1011-1018, 2014.

28. Zhou N, Qu Y, Xu C and Tang Y: Upregulation of microRNA-375 increases the cisplatin-sensitivity of human gastric cancer cells by regulating ERBB2. Exp Ther Med 11: 625-630, 2016.

29. Du Y, Zhu M, Zhou X, Huang Z, Zhu J, Xu J, Cheng G, Shu Y, Liu P, Zhu W and Wang T: MiR-20a enhances cisplatin resistance of human gastric cancer cell line by targeting NFKBIB. Tumour Biol 37: 1261-1269, 2016
30. Livak KJ and Schmittgen TD: Analysis of relative gene expression data using real-time quantitative PCR and the 2(-Delta Delta C(T)) method. Methods 25: 402-408, 2001

31. Liu J, Ahiekpor A, Li L, Li X, Arbuthnot P, Kew M and Feitelson MA: Increased expression of ErbB-2 in liver is associated with hepatitis $\mathrm{B} \times$ antigen and shorter survival in patients with liver cancer. Int J Cancer 125: 1894-1901, 2009.

32. Sun K and Lai EC: Adult-specific functions of animal microRNAs. Nat Rev Genet 14: 535-548, 2013.

33. Kasinski AL and Slack FJ: Epigenetics and genetics. MicroRNAs en route to the clinic: Progress in validating and targeting microRNAs for cancer therapy. Nat Rev Cancer 11: 849-864, 2011.

34. Iorio MV and Croce CM: MicroRNA dysregulation in cancer: Diagnostics, monitoring and therapeutics. A comprehensive review. EMBO Mol Med 4: 143-159, 2012.

35. Valencia-Sanchez MA, Liu J, Hannon GJ and Parker R: Control of translation and mRNA degradation by miRNAs and siRNAs. Genes Dev 20: 515-524, 2006.

36. Poy MN, Eliasson L, Krutzfeldt J, Kuwajima S, Ma X, Macdonald PE, Pfeffer S, Tuschl T, Rajewsky N, Rorsman P and Stoffel M: A pancreatic islet-specific microRNA regulates insulin secretion. Nature 432: 226-230, 2004.

37. Avnit-Sagi T, Kantorovich L, Kredo-Russo S, Hornstein E and Walker MD: The promoter of the pri-miR-375 gene directs expression selectively to the endocrine pancreas. PLoS One 4: e5033, 2009

38. Liu AM, Poon RT and Luk JM: MicroRNA-375 targets Hippo-signaling effector YAP in liver cancer and inhibits tumor properties. Biochem Biophys Res Commun 394: 623-627, 2010.

39. Poy MN, Hausser J, Trajkovski M, Braun M, Collins S, Rorsman P, Zavolan M and Stoffel M: MiR-375 maintains normal pancreatic alpha- and beta-cell mass. Proc Natl Acad Sci USA 106: 5813-5818, 2009

40. Kloosterman WP, Lagendijk AK, Ketting RF, Moulton JD and Plasterk RH: Targeted inhibition of miRNA maturation with morpholinos reveals a role for miR-375 in pancreatic islet development. PLoS Biol 5: e203, 2007.

41. Shen ZY, Zhang ZZ, Liu H, Zhao EH and Cao H: MiR-375 inhibits the proliferation of gastric cancer cells by repressing ERBB2 expression. Exp Ther Med 7: 1757-1761, 2014.

42. Zhang ZW, Men T, Feng RC, Li YC, Zhou D and Teng CB: MiR-375 inhibits proliferation of mouse pancreatic progenitor cells by targeting YAP1. Cell Physiol Biochem 32: 1808-1817, 2013.

43. Mitri Z, Constantine T and O'Regan R: The HER2 receptor in breast cancer: Pathophysiology, clinical use, and new advances in therapy. Chemother Res Pract 2012: 743193, 2012. 